\title{
Transactions
}

\section{CXCR4 chemokine receptor antagonists: nickel(II) complexes of configurationally restricted macrocycles $\phi$}

\author{
Rachel Smith, ${ }^{a}$ Dana Huskens, ${ }^{b}$ Dirk Daelemans, ${ }^{b}$ Ryan E. Mewis, ${ }^{a}$ Courtney D. Garcia, ${ }^{c}$ Amy N. Cain, ${ }^{c}$ \\ TaRynn N. Carder Freeman, ${ }^{c}$ Christophe Pannecouque, ${ }^{b}$ Erik De Clercq, ${ }^{b}$ Dominique Schols, ${ }^{b}$ \\ Timothy J. Hubin ${ }^{c}$ and Stephen J. Archibald ${ }^{* a}$
}

Received 25th May 2012, Accepted 11th July 2012

DOI: $10.1039 / \mathbf{c} 2 \mathrm{dt31137b}$

Tetraazamacrocyclic complexes of transition metals provide useful units for incorporating multiple coordination interactions into a single protein binding molecule. They can be designed with available sites for protein interactions via donor atom-containing amino acid side chains or labile ligands, such as $\mathrm{H}_{2} \mathrm{O}$, allowing facile exchange. Three configurationally restricted nickel(II) cyclam complexes with either one or two macrocyclic rings were synthesised and their ability to abrogate the CXCR4 chemokine receptor signalling process was assessed $\left(\mathrm{IC}_{50}=8320,194\right.$ and $\left.14 \mathrm{nM}\right)$. Analogues were characterised crystallographically to determine the geometric parameters of the acetate binding as a model for aspartate. The most active nickel(II) compound was tested in several anti-HIV assays against representative viral strains showing highly potent $\mathrm{EC}_{50}$ values down to $13 \mathrm{nM}$ against $\mathrm{CXCR} 4$ using viruses, with no observed cytotoxicity $\left(\mathrm{CC}_{50}>125 \mu \mathrm{M}\right)$.

\section{Introduction}

Chemokine receptors are signalling proteins (G-protein coupled receptors) located on the cellular surface, which have key physiological roles including the recruitment of leukocytes to sites of infection and the trafficking of stem cells for organ formation at the embryonic stage. There are currently 19 known chemokine receptors with a confirmed role ${ }^{1}$ and we have been particularly interested in producing molecules to bind to the CXCR4 receptor. $^{2}$ There are only two clinically approved drugs targeting chemokine receptors: maraviroc, which targets the CCR5 receptor and is used to treat HIV infection ${ }^{3}$ and plerixafor, which targets the CXCR4 chemokine receptor ${ }^{4-7}$ and is used for haematopoietic stem cell mobilisation ${ }^{8,9}$ to allow harvesting in patients with B-cell non-Hodgkin's lymphoma and multiple myeloma prior to immuno-compromising treatment. CXCR4 is also linked with many other diseases such as arthritis, asthma, HIV infection and various types of cancer. ${ }^{10,11}$

There is a current interest in high affinity compounds that antagonise the chemokine receptor CXCR4 and block its interactions with both HIV and its cognate signalling partner

${ }^{a}$ Department of Chemistry, The University of Hull, Cottingham Road, Hull, UK, HU6 7RX.E-mail: s.j.archibald@hull.ac.uk;

Fax: + 44(0)1482466410; Tel: +44 (0)1482 465488

${ }^{b}$ Rega Institute for Medical Research, KU, Leuven, B-3000 Leuven, Belgium

${ }^{c}$ Department of Chemistry and Physics, Southwestern Oklahoma State University, Weatherford, OK 73096, USA

$\dagger$ CCDC reference numbers 891843 and 891844 . For crystallographic data in CIF or other electronic format see DOI: $10.1039 / \mathrm{c} 2 \mathrm{dt} 31137 \mathrm{~b}$
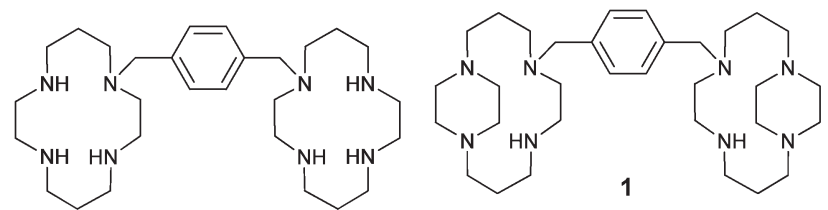

Plerixafor/ AMD3100
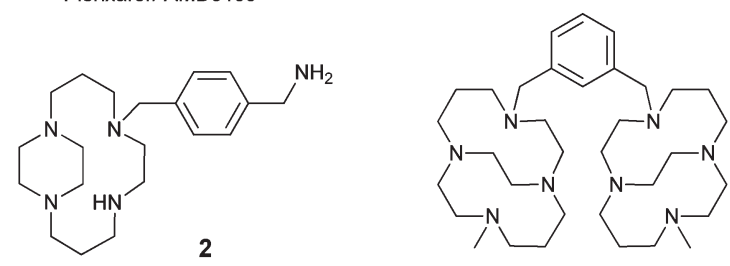

3

CXCL12. ${ }^{2}$ Our use of metal complexes shows that increased activity and receptor residence time can be achieved. ${ }^{12-16}$ Plerixafor is a cyclam based compound that contains two macrocyclic rings with an ideal ring size cavity for binding to first row transition metals. It was initially demonstrated that some of the metal complexes show increased biological activity and the key binding interactions were investigated by site directed mutagenesis. ${ }^{17,18}$

Side and cross bridged macrocyclic chelators have been developed for a variety of biomedical applications including stable complex formation with metal radioisotopes for in vivo use. ${ }^{19-24}$ They adopt a more rigid shape which impacts on the kinetics of complex formation and dissociation. ${ }^{25-27}$ They can also be used to fix the configuration of the metal complexes. The unrestricted 
cyclam ring can adopt one of six configurations on complex formation with a metal ion when binding to all four of the N-donor atoms. $^{28}$

The only nickel(II) complex investigated as a CXCR4 antagonist is the plerixafor/AMD3100 complex. ${ }^{4}$ However, nickel(II) is particularly interesting due to its varying coordination preferences. It can either form diamagnetic square planar complexes or expand its coordination sphere to incorporate additional donors. The anti-HIV data on $\left[\mathrm{Ni}_{2} \mathrm{AMD} 3100\right]^{4+}$ shows that the compound has a very similar potency to the free ligand and is lower than the equivalent zinc(II) complex. ${ }^{17}$ Following on from our previous studies on configurationally restricted macrocyclic zinc(II) complexes that showed increased potency, relative to both plerixafor and its complexes, we now extend this study to nickel(II). ${ }^{29}$

Sadler and co-workers have studied the configuration of the nickel(II) complex of plerixafor/AMD3100 and shown the adoption of the folded (cis-V) and planar (trans-III) geometries. ${ }^{30}$ They demonstrated that a configurational equilibrium exists in solution and that the cis- $\mathrm{V}$ compound can form on binding to protein aspartate residues. We selected three compounds for our studies that are all configurationally fixed by either steric interactions or a topological constraint. This is provided via an ethyl bridge between adjacent or non-adjacent nitrogens, respectively.

We have previously synthesised the piperazino side-bridged cyclam chelator 1 and studied its copper(II) and zinc(II) complexes. ${ }^{13,29} \mathrm{X}$-ray structural data revealed a trans-II macrocyclic configuration with the metal ion displaced from the plane of the macrocyclic nitrogen donors. NMR data showed that the zinc(II) complex adopts this single configuration in aqueous solution. ${ }^{29}$ Chelator $\mathbf{2}$ is a novel monomacrocyclic compound with a single primary amino group in the position of the second macrocyclic group. It was thought that this may provide an H-bonding interaction with a second aspartate/glutamate residue on binding to the protein. The third cyclam-based compound 3 incorporates two rings at the meta positions on the central phenyl ring. This shortens the distance between the two metal centres on complex formation. Nickel(II) complexes were formed and their interaction with the CXCR4 chemokine receptor probed through cellular signalling and antiviral assays.

\section{Results and discussion}

\section{Synthesis}

Compound 1 was synthesised according to our previously published route. ${ }^{29}$ The standard route to mono-substitution, required to form compound $\mathbf{2}$, was carried out using a synthesis developed from the work of Handel and co-workers, see Scheme 1. ${ }^{31}$ In this case, a cyano derivative was used to later introduce a primary amino group that offers additional H-bonding potential with the protein target or a position for subsequent functionalisation (not used in this work). We have previously synthesised a compound with an aniline amino group that has a shorter distance to the macrocycle and reduced flexibility for the orientation of the primary amine. ${ }^{12}$ The substitution reaction and sodium borohydride reaction proceed in high yields $(71 \%$ overall for the two steps). Reduction of the cyano group was then carried out using lithium aluminium hydride to give the desired product in an $86 \%$ yield.

The meta-substituted bis-macrocyclic derivative $\mathbf{3}$ was synthesised according to a procedure developed for the analogous para-derivative. The first step was again carried out using a modified version of Handel and co-workers reaction and the final two steps by our published procedure, which is based on protocols developed by Weisman and co-workers. ${ }^{23,24,31}$ The final two steps (methylation and reduction) resulted in the isolation of the desired product in an overall 59\% yield.

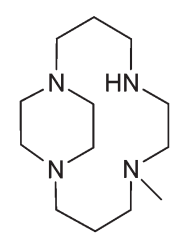

8

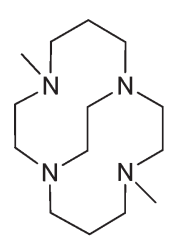

9

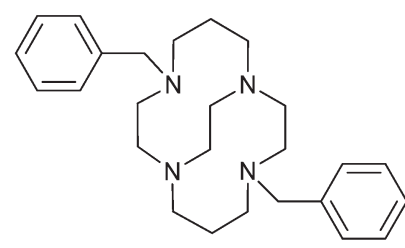

10
Nickel(II) complexes were formed by stirring with an appropriate metal salt at RT or heating in a methanolic solution. The orange colour $\left(\lambda_{\max }=c a .480 \mathrm{~nm}\right)$ of the complexes formed with chelators $\mathbf{1}$ and $\mathbf{2}$ indicates a square planar coordination environment. However, the brown colour of $\left[\mathrm{Ni}_{2} 3\right]^{4+}$ indicates a six coordinate geometry. To produce single crystals of the related complexes, nickel(II) compounds were also synthesised with known ligands (8, 9 and 10) using similar procedures.

\section{Single crystal X-ray crystallographic studies}

X-ray crystallographic studies were carried out to determine the exact geometric parameters of the nickel(II) coordination, see Tables 1 and 2. We did not have any success in growing crystals of sufficient quality for single crystal X-ray structural determination of the nickel(II) complexes of $\mathbf{1}, \mathbf{2}$ or $\mathbf{3}$ and so model systems were studied using chelators $\mathbf{8}, \mathbf{9}$ and $\mathbf{1 0}$ that were more amenable to crystallisation. Three single ring cross bridged nickel(II) complexes were crystallised. The chelating ligands 9 and 10 were used to give an indication of the steric impact of methyl vs. benzyl N-substitution on the acetate interaction as a model for aspartate binding in the protein. A search of the crystallographic database was carried out to find known structures for comparison.

There are currently no side bridged (piperazino) cyclam nickel(II) complexes deposited in the Cambridge Structural Database. ${ }^{33}$ We prepared the nickel(II) complex of the known mono- $N$-methyl piperazino cyclam 8 . A full structural refinement was not possible due to the low data quality but the coordination geometry around the nickel(II) and the ligand configuration were clear, see Fig. 1. The trans-II configuration is consistent with all the other X-ray structures known for piperazino methyl cyclam-based chelators. It can be compared to the nickel(II) perchlorate complex of the piperazino side bridged cyclen, which was initially prepared by Ramasubbu and Wainwright and the crystal structure reported later. ${ }^{34,35}$ The UV-vis spectrum contains a band centred at approximately $480 \mathrm{~nm}$, indicating a 


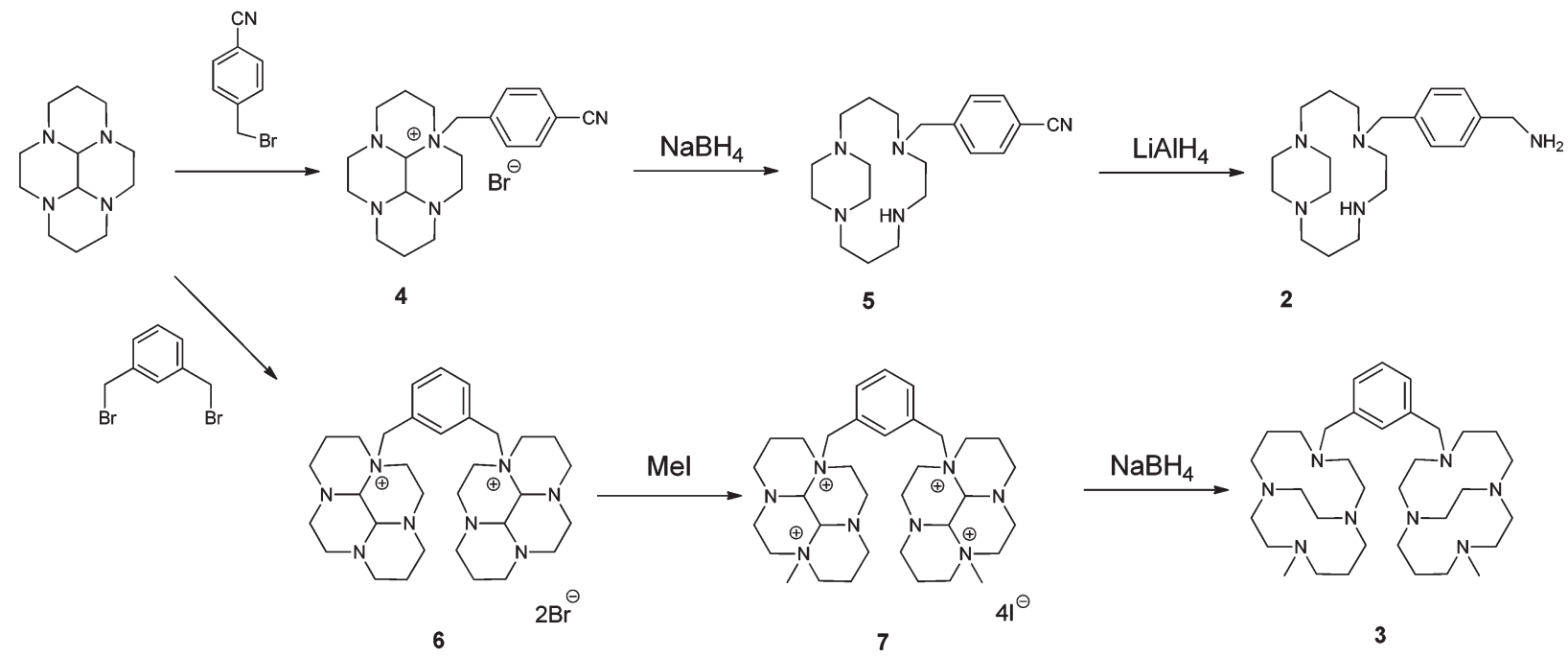

Scheme 1 Synthetic routes to produce the novel chelators $\mathbf{2}$ and $\mathbf{3}$.

Table 1 Crystal data for the single crystal X-ray structures of Ni9 and Ni10

\begin{tabular}{|c|c|c|}
\hline & {$\left[\mathrm{Ni9}(\mathrm{OAc}) \mathrm{OH}_{2}\right]^{+}$} & {$\left[\mathrm{Ni10}(\mathrm{OAc}) \mathrm{OH}_{2}\right]^{+}$} \\
\hline Formula & $\mathrm{C}_{16} \mathrm{H}_{35} \mathrm{~N}_{4} \mathrm{O}_{3} \mathrm{~F}_{6} \mathrm{NiP}$ & $\mathrm{C}_{29} \mathrm{H}_{45} \mathrm{~N}_{4} \mathrm{O}_{4} \mathrm{~F}_{6} \mathrm{NiP}$ \\
\hline $\mathrm{M}_{\mathrm{r}}$ & 535.16 & 717.37 \\
\hline Crystal system & Trigonal & Triclinic \\
\hline Space group & $R 3 c$ & $P \overline{1}$ \\
\hline$a(\AA)$ & $26.005(2)$ & $10.2997(14)$ \\
\hline$b(\AA)$ & $26.005(2)$ & $10.4483(13)$ \\
\hline$c(\AA)$ & $17.2968(11)$ & 16.902 \\
\hline$\alpha\left({ }^{\circ}\right)$ & 90 & $98.981(10)$ \\
\hline$\beta\left({ }^{\circ}\right)$ & 90 & $104.607(10)$ \\
\hline$\gamma\left({ }^{\circ}\right)$ & 120 & $106.546(11)$ \\
\hline Volume $\left(\AA^{3}\right)$ & $10129.9(13)$ & $1635.2(4)$ \\
\hline$Z$ & 18 & 2 \\
\hline Density (calc.) $\left(\mathrm{M} \mathrm{gm}^{-3}\right)$ & 1.579 & 1.457 \\
\hline$\mu \mathrm{Mo}-\mathrm{K} \alpha\left(\mathrm{mm}^{-1}\right)$ & 1.008 & 0.717 \\
\hline$T(\mathrm{~K})$ & 150 & 150 \\
\hline$\theta$ range $\left(^{\circ}\right)$ & 2.52 to 34.73 & 2.57 to 34.87 \\
\hline Measured reflections & 18505 & 37739 \\
\hline Unique reflections $\left[R_{\mathrm{int}}\right]$ & 8024 [0.0839] & $13881[0.0864]$ \\
\hline Completeness $\left(\theta^{\circ}\right)$ & $99.5 \%(34.73)$ & $99.8 \%(25.00)$ \\
\hline Goodness-of-fit on $F^{2}$ & 0.681 & 0.907 \\
\hline$R_{1}, w R_{2}(I>2 \sigma(I))$ & $0.0404,0.0717$ & $0.0852,0.2159$ \\
\hline$R_{1}, w R_{2}$ (all data) & $0.1165,0.0815$ & $0.1642,0.2680$ \\
\hline Extinction coefficient & $0.035(12)$ & $0.161(9)$ \\
\hline $\begin{array}{l}\text { Largest diff. peak and hole } \\
\left(\mathrm{e} \AA^{-3}\right)\end{array}$ & 0.766 and -0.381 & 1.108 and -1.003 \\
\hline
\end{tabular}

square planar coordination geometry in aqueous solution. The X-ray structure confirms the distorted square planar environment with nickel(II)-nitrogen bond lengths of $c a$. 1.85 to $1.88 \AA$. The nickel(II) centre sits out of the mean nitrogen plane by $0.2 \AA$ with the piperazino unit in the expected boat conformation to position the two nitrogen lone pairs into the cavity.

The structure of $\left[\mathrm{Ni9OAc}\left(\mathrm{OH}_{2}\right)\right]^{+}$shows an octahedral nickel(II) centre with a cis arrangement of a monodentate acetate and a water molecule, giving a distorted octahedral coordination geometry. The acetate and water molecules are involved in an intramolecular hydrogen bonding interaction and both have intermolecular H-bonds with neighbouring complexes, see Table 3.
Table 2 Selected bond lengths $(\AA)$ and angles $\left(^{\circ}\right)$ for the single crystal $\mathrm{X}$-ray structures of $\mathrm{Ni9}$ and $\mathrm{Ni10}$

\begin{tabular}{lll}
\hline & $\begin{array}{l}\text { Bond lengths/ } \\
\text { angles Ni9 }\end{array}$ & $\begin{array}{l}\text { Bond lengths/ } \\
\text { angles Ni10 }\end{array}$ \\
\hline $\mathrm{Ni}$-N1/N22 & $2.091(3)$ & $2.135(3)$ \\
$\mathrm{Ni}-\mathrm{N} 2 / \mathrm{N} 23$ & $2.181(3)$ & $2.188(3)$ \\
$\mathrm{Ni}-\mathrm{N} 3 / \mathrm{N} 21$ & $2.103(3)$ & $2.128(3)$ \\
$\mathrm{Ni}-\mathrm{N} 4 / \mathrm{N} 10$ & $2.202(3)$ & $2.177(3)$ \\
$\mathrm{Ni}-\mathrm{O} 1$ & $2.064(2)$ & $2.052(2)$ \\
$\mathrm{Ni}-\mathrm{O} 1 \mathrm{~W} / \mathrm{O} 3$ & $2.077(3)$ & $2.109(3)$ \\
$\mathrm{N} 1-\mathrm{Ni}-\mathrm{N} 2 / \mathrm{N} 22-\mathrm{Ni}-\mathrm{N} 23$ & $84.15(10)$ & $85.66(12)$ \\
$\mathrm{N} 1-\mathrm{Ni}-\mathrm{N} 3 / \mathrm{N} 22-\mathrm{Ni}-\mathrm{N} 21$ & $84.02(10)$ & $85.50(12)$ \\
$\mathrm{N} 1-\mathrm{Ni}-\mathrm{N} 4 / \mathrm{N} 22-\mathrm{Ni}-\mathrm{N} 10$ & $91.29(11)$ & $91.70(12)$ \\
$\mathrm{N} 2-\mathrm{Ni}-\mathrm{N} 3 / \mathrm{N} 23-\mathrm{Ni}-\mathrm{N} 21$ & $90.67(11)$ & $91.74(11)$ \\
$\mathrm{N} 2-\mathrm{Ni}-\mathrm{N} 4 / \mathrm{N} 23-\mathrm{Ni}-\mathrm{N} 10$ & $173.41(11)$ & $175.41(10)$ \\
$\mathrm{N} 3-\mathrm{Ni}-\mathrm{N} 4 / \mathrm{N} 21-\mathrm{Ni}-\mathrm{N} 10$ & $84.11(10)$ & $84.30(11)$ \\
$\mathrm{O} 1-\mathrm{Ni}-\mathrm{N} 1 / \mathrm{O} 1-\mathrm{Ni}-\mathrm{N} 22$ & $91.19(10)$ & $88.93(11)$ \\
$\mathrm{O} 1-\mathrm{Ni}-\mathrm{N} 2 / \mathrm{O} 1-\mathrm{Ni}-\mathrm{N} 23$ & $95.08(10)$ & $93.31(10)$ \\
O1-Ni-N3/O1-Ni-N21 & $172.12(10)$ & $172.18(11)$ \\
O1-Ni-N4/O1-Ni-N10 & $89.76(10)$ & $90.39(11)$ \\
$\mathrm{O} 1 \mathrm{~W}-\mathrm{Ni}-\mathrm{N} 1 / \mathrm{O} 3-\mathrm{Ni}-\mathrm{N} 22$ & $170.63(10)$ & $170.47(11)$ \\
$\mathrm{O} 1 \mathrm{~W}-\mathrm{Ni}-\mathrm{N} 2 / \mathrm{O} 3-\mathrm{Ni}-\mathrm{N} 23$ & $86.56(10)$ & $85.44(11)$ \\
$\mathrm{O} 1 \mathrm{~W}-\mathrm{Ni}-\mathrm{N} 3 / \mathrm{O} 3-\mathrm{Ni}-\mathrm{N} 21$ & $97.39(10)$ & $98.17(12)$ \\
O1W-Ni-N4/O3-Ni-N10 & $98.06(11)$ & $97.39(11)$ \\
O1-Ni-O1W/O1-Ni-O3 & $88.35(10)$ & $88.18(11)$ \\
\hline
\end{tabular}

The Hirshfeld surfaces clearly indicate the direction of these interactions, see Fig. 2. The $\left[\mathrm{Ni10OAc}\left(\mathrm{OH}_{2}\right)\right]^{+}$structure has the same coordination sphere but an additional solvent molecule involved in a H-bonding interaction, see Table 3 and Fig. 2. The two structures have very similar bond lengths and angles, with the nickel(II) atom sitting very slightly further into the cavity for the complex with $\mathbf{9}$, as demonstrated by the comparison between the bond lengths and angles for the ethyl linked N-donors N1 and N3.

There are two cross bridged nickel(II) cyclam structures deposited in the crystallographic database (reference codes: AGIXIX and AGIXUJ). ${ }^{36}$ However, of greater relevance to this study are the nickel(II) complexes of cyclam-based macrocycles that have a bound carboxylate ligand, with 103 such structures in the 

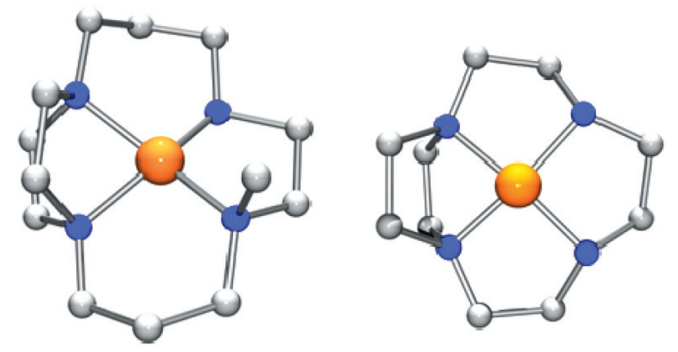

Fig. 1 X-ray structures of nickel(II) piperazino methylcyclam $\left([\mathrm{Ni8}]^{2+}\right)$ and the piperazinocyclen macrocyclic complexes. (The cyclam complex from this work and the cyclen complex from Hancock and coworkers). ${ }^{32}$

Table 3 Hydrogen bonds with $\mathrm{H} \cdots \mathrm{A}<r(\mathrm{~A})+2.0 \AA$ and DHA $>110^{\circ}$

\begin{tabular}{|c|c|c|c|c|}
\hline $\mathrm{D}-\mathrm{H} \cdots \mathrm{A}$ & $\begin{array}{l}d(\mathrm{D}-\mathrm{H}) \\
(\AA)\end{array}$ & $\begin{array}{l}d(\mathrm{H} \cdots \mathrm{A}) \\
(\AA)\end{array}$ & $\begin{array}{l}<\text { DHA } \\
\left(^{\circ}\right)\end{array}$ & $\begin{array}{l}d(\mathrm{D} \cdots \mathrm{A}) \\
(\AA)\end{array}$ \\
\hline \multicolumn{5}{|l|}{$\left[\mathrm{Ni9OAc}\left(\mathrm{OH}_{2}\right)\right]^{+}$} \\
\hline $\mathrm{O} 1 \mathrm{~W}-\mathrm{H} 1 \mathrm{C} \cdots \mathrm{O} 2^{b}$ & 0.821 & 1.958 & 155.35 & 2.726 \\
\hline 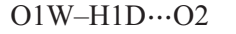 & 0.852 & 1.802 & 173.99 & 2.651 \\
\hline $\mathrm{O} 1 \mathrm{~W}-\mathrm{H} 1 \mathrm{D} \cdots \mathrm{O} 1$ & 0.852 & 2.446 & 114.13 & 2.900 \\
\hline \multicolumn{5}{|c|}{$\left[\mathrm{Ni10OAc}\left(\mathrm{OH}_{2}\right) \mathrm{MeOH}^{2+}\right.$} \\
\hline $\mathrm{O} 3-\mathrm{H} 1 \mathrm{O} 3 \cdots \mathrm{O} 2$ & 0.788 & 1.933 & 153.65 & 2.662 \\
\hline $\mathrm{O} 3-\mathrm{H} 2 \mathrm{O} 3 \cdots \mathrm{O}^{a}{ }^{a}$ & 0.879 & 1.805 & 172.59 & 2.680 \\
\hline $\mathrm{O} 4-\mathrm{H} 4 \mathrm{C} \cdots \mathrm{O} 2$ & 0.836 & 1.804 & 169.96 & 2.632 \\
\hline
\end{tabular}

CSD. The large number appears to be due to the popularity of this motif in crystal engineering, metal-organic frameworks and coordination polymer formation.

This search was refined by limiting the hits to only the coordination to the carboxylate component of the additional ligand (i.e. amino acids that also have $\mathrm{N}$-donor binding were excluded). The majority of the structures, including a large number of examples showing coordination polymer formation using bis-carboxylates, have the trans-III cyclam ring configuration ${ }^{28}$ with a six coordinate octahedral nickel(II) centre. The four $\mathrm{N}$-donors are planar with further ligands above and below the ring plane to give an octahedral geometry (typical example: NEXQAJ). ${ }^{30}$ Our assumption is that a single carboxylate from the peptidic side chain in the CXCR4 protein is bound to our compounds from one side of the ring, due to the steric/topological constraint of including an ethyl bridge, and so these structures were excluded from further analysis. Seventeen structures with bound acetate groups that are not planar were found, comprising fourteen bidentate $c i s-\mathrm{V}$ structures (including the structure determined by Sadler and co-workers in their study of configuration $)^{37}$ and three structures containing monodentate acetate ligands, with two of them including a bound water molecule.

One compound has a bulky acetate group forcing a five coordinate geometry (distorted square based pyramidal) with an unusual trans-IV ring configuration and a monodentate acetate (ILOCUI). ${ }^{38} \mathrm{~A}$ cyclam derivative, with two of the nitrogens cyclised to form a more rigid chelator, adopts a very similar geometry to that observed for the compounds in this work, with a cis $-\mathrm{V}$ macrocycle configuration and an identical coordination sphere, including a bound water molecule and monodentate acetate (CEBKOK). ${ }^{39}$ The most striking structure in the database for comparison is one where two C-alkylated cyclam nickel(II) complexes (tetA) are bridged by a bis-carboxylate (MASVOS) ${ }^{40}$ This contains one metal centre which is six coordinate with a coordinated water molecule and a monodentate acetate ligand and a second metal centre which is six coordinate with a bidentate acetate. The appearance of both binding modes in separate identical macrocyclic species within the asymmetric unit suggests a fine energetic balance between the two structural types.

\section{Biological assays: calcium signalling and anti-HIV activity}

An initial screen of the compounds was carried out using a calcium signalling assay in response to stimulation by the chemokine protein binding partner of the CXCR4 receptor, CXCL12. The concentration of intracellular calcium released was measured and the abrogation of this flux by the antagonists was recorded at a series of concentrations to give a value whereby a $50 \%$ reduction was observed, see Table 4 . The bisring nickel(II) complexes show a higher potency than the mono ring compound $[\mathrm{Ni} 2]^{2+}$, which is only active at a micromolar level. Due to its relatively low activity, this compound was excluded from further studies. The para side bridged compound $\left[\mathrm{Ni}_{2} \mathbf{1}\right]^{4+}$ was significantly more active than the meta cross bridged compound and 2 -fold more active than plerixafor. The cytotoxicity of the three nickel(II) complexes was measured in MT-4 cells as a $\mathrm{CC}_{50}$ (a cytotoxic effect that reduces cell viability by $50 \%$ ) and in all cases this was greater than $125 \mu \mathrm{M}$, the maximum value tested. It is anticipated that the metal free macrocyclic compounds $\mathbf{1}, \mathbf{2}$ and $\mathbf{3}$ will have considerably lower activity, consistent with the analysis of related ethyl bridged macrocycles, due to the reduction in H-bond donors compared to plerixafor. ${ }^{14,29}$

An initial anti-HIV assay was carried out with the two bismacrocyclic compounds using plerixafor as a comparison and an X4 viral strain that utilises CXCR4 as a co-receptor for viral entry rather than CCR5. In this assay, the meta compound $[\mathrm{Ni3}]^{4+}$ was again less active than the para compound $[\mathrm{Ni1}]^{2+}$, which shows a similar activity to plerixafor. On this basis, $[\mathrm{Ni1}]^{2+}$ was selected for further studies of anti-viral activity against a selected series of different viral strains: HIV-1, HIV-2 and SIV. Activity was observed against both HIV-1 and HIV-2 in two cell lines (MT-4 and Jurkat) and also in peripheral blood mononuclear cells (PBMCs), as these are the most relevant cellular model for evaluating HIV replication, see Table 5.

High activity was observed against the wild type NL4.3, which can be used as a reference for mutated viral strains. For comparison, nevirapine, a non-nucleoside reverse transcriptase inhibitor (NNRTI), that is currently used in clinical antiretroviral drug combinations for treatment of HIV/AIDS, was also analysed against NL4.3. Nevirapine is $c a$. 50 times more active than $\left[\mathrm{Ni}_{2} \mathbf{1}\right]^{4+}$. However, nevirapine has a much higher cytotoxicity value $\left(\mathrm{CC}_{50}\right)$ of $2 \mu \mathrm{g} \mathrm{mL} L^{-1}$ giving a lower selectivity index of $400 v s>5000$ for $\left[\mathrm{Ni}_{2} \mathbf{1}\right]^{4+}$. 

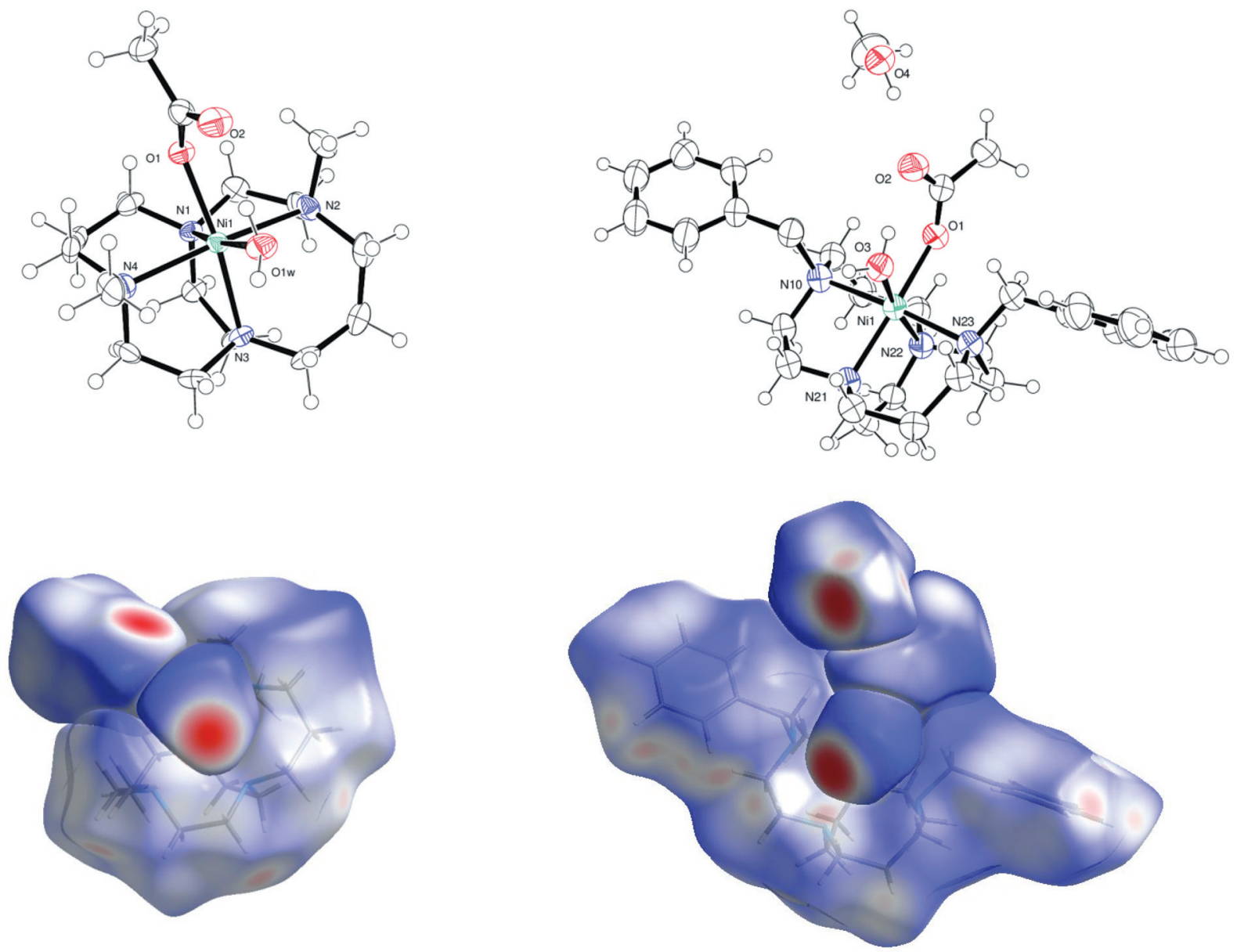

Fig. 2 ORTEP and Hirshfeld surface plots of $\left[\mathrm{Ni9OAc}\left(\mathrm{OH}_{2}\right)\right]^{+}$and $\left[\mathrm{Ni10OAc}\left(\mathrm{OH}_{2}\right)\right]^{+}$.

Table 4 Calcium signalling inhibition and anti-HIV activity (nM)

\begin{tabular}{lll}
\hline Compound & $\begin{array}{l}\mathrm{Ca}^{2+} \text { flux } \mathrm{IC}_{50} \\
\mathrm{CXCR}^{a}(\mathrm{nM})\end{array}$ & $\begin{array}{l}\text { Anti-HIV-1 } \\
\text { av. } \mathrm{EC}_{50}{ }^{c}(\mathrm{nM})\end{array}$ \\
\hline$\left[\mathrm{Ni}_{2} \mathbf{1}\right]^{4+}$ & 14 & 74 \\
{$\left[\mathrm{Ni}_{2}\right]^{2+}$} & 8320 & - \\
{$\left[\mathrm{Ni}_{2} 3\right]^{4+}$} & 194 & 398 \\
Plerixafor & 31 & 11
\end{tabular}

${ }^{a} \mathrm{U} 87 . \mathrm{CXCR} 4$ cell line. $\mathrm{IC}_{50}$ is the concentration of the compound required to inhibit $50 \%$ of the CXCL12 (SDF-1) induced $\mathrm{Ca}^{2+}$ signalling. ${ }^{b}$ The assay was carried out in a $\mathrm{CD} 4^{+} \mathrm{CXCR} 4^{+} \mathrm{T}$ cell line, MT-4 cells, using the HIV-1 X4 strain $\mathrm{III}_{\mathrm{B}}$. ${ }^{c}$ Average effective concentration to reduce the HIV-induced cytopathic effect by $50 \%$ in MT-4 cells.

Resistant viral strains were also investigated. They were developed by repeat passaging and selection of the virus under challenge from AMD3100/plerixafor. It is assumed that the binding site for $\left[\mathrm{Ni}_{2} \mathbf{1}\right]^{2+}$ will be similar to plerixafor and so similar resistance may be observed. This was the case, as a drop in activity but not complete resistance was observed. Competition with AMD3100/plerixafor for inhibition of the resistant viral strain did not show a significant impact on the activity.

Experiments were carried out to determine the activity against two viral strains that use the CCR5 co-receptor rather than
CXCR4 for HIV cell entry: BaL and MAC251. As expected, no activity was observed as the compounds synthesised are proposed to be selective CXCR4 antagonists. To confirm this, $[\mathrm{Ni1}]^{4+}$ was also tested in a CCR5 signalling abrogation assay and shown to have no effect up to a concentration of $1 \mu \mathrm{M}$.

\section{Conclusions}

Two novel chelators and three novel nickel(II) complexes were synthesised. X-ray crystal structures of related complexes were used to infer possible binding modes when interacting with the aspartate side chains of the CXCR4 protein. The para arrangement of the macrocyclic components appears to be essential for the high activity of the two ring compounds. The most active compound showed highly potent anti-HIV activity (13 nM) against the X4 NL4.3 viral strain and improved the blocking of CXCL12/CXCR4 signalling compared to AMD3100/plerixafor. There is potential for further development of configurationally restricted nickel(II) macrocyclic compounds to optimise both the arrangement of the units and binding with protein aspartate residues. The X-ray structural data showed that a water molecule can also be coordinated to the metal centre. This could be incorporated when bound to the protein but analysis of the related structures in the crystallographic database suggested a fine 
Table 5 Anti-HIV activity $(\mathrm{nM})$ of $\left[\mathrm{Ni}_{2} \mathbf{1}\right]^{4+}$ in assays using three different cell lines

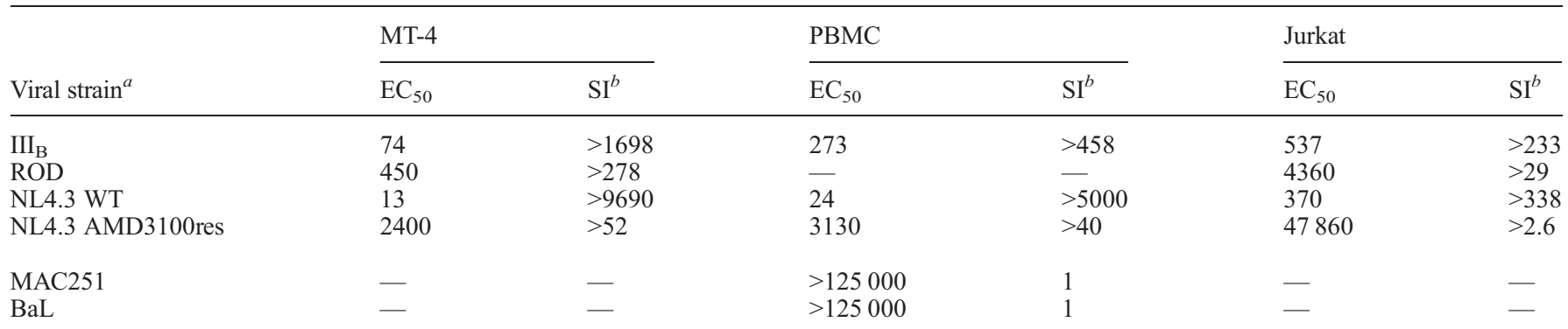

${ }^{a} \mathrm{III}_{\mathrm{B}}$ (HIV-1), ROD (HIV-2), NL4.3 WT (HIV-1), NL4.3 AMD3100res (AMD3100 resistant strain of HIV-1 NL4.3), MAC251 (R5 SIV strain) and HIV-1 BaL (R5 HIV-1 strain). ${ }^{b}$ Selectivity index based on the ratio of $\mathrm{CC}_{50}$ to $\mathrm{EC}_{50}$.

energetic balance between a bidentate acetate or a monodentate acetate and a water molecule.

We have demonstrated that nickel(II) complexes can have low cytotoxicity and high potency against HIV, offering excellent selectivity indices. The flexible coordination sphere of nickel(II) is a good match for introducing strong binding interactions with the protein amino acid residues and offers significant scope for the future development of metallodrugs.

\section{Experimental}

NMR spectra were obtained using a JEOL400 spectrometer. UV-vis spectra were obtained using an Agilent 800 diode spectrometer. Electrospray mass spectra were obtained using a Finnigan LCQ spectrometer. Accurate mass measurements were carried out by the EPSRC's National Mass Spectrometry Service at Swansea. All materials were purchased from Aldrich Chemical Co. or Lancaster Synthesis Ltd, and used as supplied. Cyclam, ${ }^{41}$ glyoxal cyclam, ${ }^{31} \mathbf{6},{ }^{31} \mathbf{8},{ }^{42} \mathbf{9}$ and $\mathbf{1 0}^{24}$ were synthesised in accordance with literature procedures. Compounds $\mathbf{1}^{29}$ and $\mathbf{4}^{23}$ were synthesised by our previously reported methods. Solvents were dried over molecular sieves prior to use. ${ }^{43}$

Diffraction data sets were collected on a Stoe IPDS-II image plate diffractometer, using Mo-K $\alpha(0.71073 \AA)$ radiation. The crystal was kept at a temperature of $150(1) \mathrm{K}$ during data collection, controlled using the Oxford Cryosystems Cryostream Cooler. ${ }^{44}$ Data sets were all collected to $\theta=35^{\circ}$ but truncated where necessary. For weakly diffracting crystals, refinement was attempted with both full and truncated data sets. All structures were solved by direct methods $\left(\right.$ SHELXS $\left.{ }^{45}\right)$ and refined against $F^{2}\left(\right.$ SHELXL $\left.^{46}\right)$. Hydrogen atoms located on carbon atoms were placed geometrically and refined against a riding model with $U_{\text {iso }}=1.2 U_{\text {eq }}$ of the carrier atom or $U_{\text {iso }}=1.5 U_{\text {eq }}$ for methyl groups. The WinGX package was used for the refinement and production of data tables and ORTEP-3 was used for the structure visualisation. ${ }^{47}$ Hydrogen bonding was determined using SHELXL and by the generation of Hirshfeld surface plots based on $d_{\text {norm }}$ using CrystalExplorer. ${ }^{48}$ All ORTEP representations show ellipsoids at a $50 \%$ probability level.

WARNING: Perchlorate salts are potentially explosive when dry. Although no problems were encountered in these preparations, care should be exercised when using these compounds.
Synthesis of 1-[4-cyanobenzyl]-1,4,8,11-tetraazabicyclo[10.2.2]hexadecane, 5

3a-[4-Cyanobenzyl]-decahydro-3a,5a,8a,10a-tetraaza-pyrenium bromide (4) $(1.00 \mathrm{~g}, 2.4 \mathrm{mmol})$ was dissolved in ethanol $(100 \mathrm{~mL})$. Sodium borohydride $(2.27 \mathrm{~g}, 60.0 \mathrm{mmol})$ was added in small portions and the mixture was stirred for 30 minutes then heated to reflux for 2 hours. Water $(100 \mathrm{~mL})$ was added to decompose any excess sodium borohydride and the solvents were removed in vacuo. The residue was taken up into water $(150 \mathrm{~mL})$ and made strongly basic $(\mathrm{pH} \mathrm{14}, \mathrm{KOH})$. The basic solution was extracted with DCM $(4 \times 150 \mathrm{~mL})$ and the combined organic extracts were dried $\left(\mathrm{Na}_{2} \mathrm{SO}_{4}\right)$, filtered and evaporated in vacuo to yield a colourless oil. Yield $=93 \%$. ${ }^{1} \mathrm{H}$ NMR (400 MHz, $\left.\mathrm{CDCl}_{3}, \delta\right): 1.62-1.71\left(\mathrm{~m}, \mathrm{~N}-\mathrm{\beta}_{-} \mathrm{CH}_{2}, 4 \mathrm{H}\right), 2.18(\mathrm{~m}$, $\mathrm{N}-\alpha-\mathrm{CH}_{2}, 2 \mathrm{H}$ ), 2.45-2.61 (m, N- $\left.\alpha-\mathrm{CH}_{2}, 12 \mathrm{H}\right), 2.80$ (t, N- $\alpha-\mathrm{CH}_{2}$, 2H), 2.96 (m, N- $\left.\alpha-\mathrm{CH}_{2}, 2 \mathrm{H}\right), 3.12$ (m, N- $\left.\alpha-\mathrm{CH}_{2}, 2 \mathrm{H}\right), 3.61$ (s, $\mathrm{Ar} \mathrm{CH}_{2}$ and NH, 3H), 7.35 (d, Ar H, 2H), 7.54 (m, H-Ar, 2H). ${ }^{13} \mathrm{C}\left\{{ }^{1} \mathrm{H}\right\}$ NMR $\left(\mathrm{CDCl}_{3}\right): \delta 23.46\left(\mathrm{~N}-\beta-\mathrm{CH}_{2}\right), 25.80\left(\mathrm{~N}-\mathrm{\beta}-\mathrm{CH}_{2}\right)$, $48.08\left(\mathrm{~N}-\alpha-\mathrm{CH}_{2}\right), \quad 48.16 \quad\left(\mathrm{~N}-\alpha-\mathrm{CH}_{2}\right), \quad 50.03 \quad\left(\mathrm{~N}-\alpha-\mathrm{CH}_{2}\right)$, $51.16\left(\mathrm{~N}-\alpha-\mathrm{CH}_{2}\right), 54.49\left(\mathrm{~N}-\alpha-\mathrm{CH}_{2}\right), 54.76\left(\mathrm{~N}-\alpha-\mathrm{CH}_{2}\right), 54.98$ $\left(\mathrm{N}-\alpha-\mathrm{CH}_{2}\right), 56.78\left(\mathrm{~N}-\alpha-\mathrm{CH}_{2}\right), 57.53\left(\mathrm{Ar} \mathrm{CH}_{2}\right), 110.67$ (Ar C), 118.80 (CN), 129.71 (Ar CH), 131.80 (Ar CH), 144.41 (Ar C). HRMS: $[\mathrm{M}+\mathrm{H}]^{+}$calcd for $\mathrm{C}_{20} \mathrm{H}_{31} \mathrm{~N}_{5} \mathrm{~m} / z=342.2658$, found $m / z=342.2652$.

\section{Synthesis of 1-[4-aminomethylbenzyl]-1,4,8,11-tetraazabicyclo- [10.2.2] hexadecane, 2}

Lithium aluminium hydride $(0.63 \mathrm{~g}, 16.70 \mathrm{mmol})$ was suspended in dry THF (20 mL). 1-[4-Cyanobenzyl]-1,4,8,11-tetraazabicyclo[10.2.2] hexadecane (6) $(1.90 \mathrm{~g}, 5.50 \mathrm{mmol})$ in dry THF $(30 \mathrm{~mL})$ was added dropwise under ice-cooling. After complete addition, the mixture was stirred for 30 minutes and then heated to reflux for 3 hours. The reaction was cooled in an icebath, water $(0.40 \mathrm{~mL})$ was added dropwise followed by $15 \%$ sodium hydroxide $(0.40 \mathrm{~mL})$ followed by a second portion of water $(1.20 \mathrm{~mL})$. The resulting white precipitate was filtered and washed with THF $(2 \times 20 \mathrm{~mL})$ then water $(2 \times 10 \mathrm{~mL})$. The aqueous layer was made strongly basic $(\mathrm{pH} 14, \mathrm{KOH})$ and extracted with THF $(5 \times 25 \mathrm{~mL})$. The organic phases were dried $\left(\mathrm{Na}_{2} \mathrm{SO}_{4}\right)$, filtered and evaporated in vacuo to yield a yellow oil. Yield $=86 \% .{ }^{1} \mathrm{H}$ NMR $\left(400 \mathrm{MHz}, \mathrm{CDCl}_{3}, \delta\right): 1.74-1.86(\mathrm{~m}$, $\mathrm{N}-\beta-\mathrm{CH}_{2}, 4 \mathrm{H}$ ), 2.23-2.27 (m, N- $\alpha-\mathrm{CH}_{2}, 2 \mathrm{H}$ ), 2.52-2.62 (br m, 
$\left.\mathrm{N}-\alpha-\mathrm{CH}_{2}+\mathrm{NH}, 12 \mathrm{H}\right), 2.92-3.00$ (m, N- $\left.\alpha-\mathrm{CH}_{2}, 3 \mathrm{H}\right), 3.25-3.28$ (m, N- $\left.\alpha-\mathrm{CH}_{2}, 2 \mathrm{H}\right), 3.65$ (s, N- $\left.\alpha \mathrm{CH}_{2}, 1 \mathrm{H}\right), 3.73-3.76$ (m, $\mathrm{CH}_{2}-\mathrm{NH}_{2}, 2 \mathrm{H}$ ), 3.86 (s, $\left.\mathrm{Ar} \mathrm{CH}_{2}, 2 \mathrm{H}\right), 7.23-7.29$ (m, Ar H, 4H). ${ }^{13} \mathrm{C}\left\{{ }^{1} \mathrm{H}\right\}$ NMR $\left(100 \mathrm{MHz}, \mathrm{CDCl}_{3}, \delta\right): 23.37\left(\mathrm{~N}-\beta-\mathrm{CH}_{2}\right)$, $25.51\left(\mathrm{~N}-\beta-\mathrm{CH}_{2}\right), 26.07\left(\mathrm{~N}-\alpha-\mathrm{CH}_{2}\right), 30.22\left(\mathrm{~N}-\alpha-\mathrm{CH}_{2}\right), 46.11$ $\left(\mathrm{N}-\alpha-\mathrm{CH}_{2}\right), \quad 48.02 \quad\left(\mathrm{~N}-\alpha-\mathrm{CH}_{2}\right), \quad 50.45 \quad\left(\mathrm{~N}-\alpha-\mathrm{CH}_{2}\right), \quad 51.03$ $\left(\mathrm{N}-\alpha-\mathrm{CH}_{2}\right), \quad 54.59 \quad\left(\mathrm{~N}-\alpha-\mathrm{CH}_{2}\right), \quad 54.90 \quad\left(\mathrm{~N}-\alpha-\mathrm{CH}_{2}\right), \quad 55.32$ $\left(\mathrm{N}-\alpha-\mathrm{CH}_{2}\right), 56.21\left(\mathrm{~N}-\alpha-\mathrm{CH}_{2}\right), 56.85\left(\mathrm{Ar} \mathrm{CH}_{2}\right), 60.87\left(\mathrm{CH}_{2-}\right.$ $\left.\mathrm{NH}_{2}\right), 126.59$ (Ar C), $129.66(\mathrm{Ar} \mathrm{CH}), 136.15(\mathrm{Ar} \mathrm{CH}), 141.83$ (Ar C). HRMS: $[\mathrm{M}+\mathrm{H}]^{+}$calcd for $\mathrm{C}_{20} \mathrm{H}_{36} \mathrm{~N}_{5} \mathrm{~m} / \mathrm{z}=346.2971$, found $m / z=346.2969$.

\section{Synthesis of 1,3-xylyl-bis(8a[methyl]-decahydro-3a,5a,8a,10a- tetraazapyrenium) tetraiodide, 7}

6 (2.60 g, $3.7 \mathrm{mmol})$ was suspended in dry acetonitrile $(150 \mathrm{~mL})$ under nitrogen and methyl iodide $(2.31 \mathrm{~mL}, 37 \mathrm{mmol})$ was added in one portion. The resulting white suspension was stoppered and stirred at room temperature for 14 days under an atmosphere of nitrogen. At the end of the reaction time, excess methyl iodide was removed by bubbling nitrogen through the suspension for 30 minutes. The white solid was filtered off, washed with diethyl ether $(200 \mathrm{~mL})$ and dried in vacuo. Yield = 76\%. ${ }^{13} \mathrm{C}\left\{{ }^{1} \mathrm{H}\right\}$ NMR (75 MHz, DMSO, $\left.\delta\right): 16.94\left(\mathrm{~N}-\beta-\mathrm{CH}_{2}\right)$, $17.12\left(\mathrm{~N}-\beta-\mathrm{CH}_{2}\right), 44.83\left(\mathrm{~N}-\alpha-\mathrm{CH}_{3}\right), 45.08\left(\mathrm{~N}-\alpha-\mathrm{CH}_{2}\right), 46.39$ $\left(\mathrm{N}-\alpha-\mathrm{CH}_{2}\right), \quad 47.52 \quad\left(\mathrm{~N}-\alpha-\mathrm{CH}_{2}\right), \quad 49.15 \quad\left(\mathrm{~N}-\alpha-\mathrm{CH}_{2}\right), \quad 50.29$ $\left(\mathrm{N}-\alpha-\mathrm{CH}_{2}\right), \quad 58.58 \quad\left(\mathrm{~N}-\alpha-\mathrm{CH}_{2}\right), \quad 59.18 \quad\left(\mathrm{~N}-\alpha-\mathrm{CH}_{2}\right), \quad 61.77$ $\left(\mathrm{N}-\alpha-\mathrm{CH}_{2}\right), 62.73\left(\mathrm{~N}-\alpha-\mathrm{CH}_{2}\right), 73.93\left(\mathrm{C}_{\text {aminal }}\right), 74.17\left(\mathrm{C}_{\text {aminal }}\right)$, 125.88 ( $\left.\mathrm{C}_{\text {aromatic }}\right), 129.03$ ( $\left.\mathrm{C}_{\text {aromatic }}\right), 134.74$ ( $\left.\mathrm{C}_{\text {aromatic }}\right), 135.02$ $\left(\mathrm{C}_{\text {aromatic }}\right)$. MS (ES): $m / z=343.0[\mathrm{M}-\text { macrocycle }]^{+}, 237.0$ $[\mathrm{M} \text { - xylyl - macrocycle }]^{+}$. Anal. calcd for $\mathrm{C}_{34} \mathrm{H}_{58} \mathrm{~N}_{8} \mathrm{I}_{4}: \mathrm{C}$, 37.59; H, 5.38; N, 10.31; found: C 37.84, H 5.25, N 10.15.

\section{Synthesis of 1,3-xylyl-bis(8-methyl-1,4,8,11-tetraazabicyclo- [6.6.2] hexadecane, 3}

7 (3.03 g, $2.8 \mathrm{mmol})$ was dissolved in ethanol $(150 \mathrm{~mL})$. Sodium borohydride $(6.38 \mathrm{~g}, 168 \mathrm{mmol})$ was added in small portions and the clear solution was stirred at room temperature under $\mathrm{N}_{2}$ for 7 days and concentrated in vacuo. Water $(100 \mathrm{~mL})$ was added then $6 \mathrm{M} \mathrm{HCl}$ was added to decompose any excess sodium borohydride until a $\mathrm{pH}=2$ was reached. The mixture was made strongly basic $(\mathrm{pH} 14, \mathrm{KOH})$ and extracted from dichloromethane $(5 \times 100 \mathrm{~mL})$. The combined organic fractions were dried $\left(\mathrm{MgSO}_{4}\right)$, filtered and evaporated in vacuo to yield a yellow oil. The $\mathrm{HCl}$ salt was prepared by bubbling $\mathrm{HCl}$ gas into an ethanolic solution of the ligand, collecting the resultant yellow precipitate by filtration and washing it with ethanol followed by diethyl ether. Yield $=77 \% .{ }^{13} \mathrm{C}\left\{{ }^{1} \mathrm{H}\right\}$ NMR $(75 \mathrm{MHz}$, $\left.\mathrm{D}_{2} \mathrm{O}, \delta\right): 18.52\left(\mathrm{~N}-\beta-\mathrm{CH}_{2}\right), 18.91\left(\mathrm{~N}-\beta-\mathrm{CH}_{2}\right), 39.69\left(\mathrm{~N}-\alpha-\mathrm{CH}_{3}\right)$, $44.56\left(\mathrm{~N}-\alpha-\mathrm{CH}_{2}\right), 49.00\left(\mathrm{~N}-\alpha-\mathrm{CH}_{2}\right), 49.13\left(\mathrm{~N}-\alpha-\mathrm{CH}_{2}\right), 50.01$ $\left(\mathrm{N}-\alpha-\mathrm{CH}_{2}\right), 52.53\left(\mathrm{~N}-\alpha-\mathrm{CH}_{2}\right), 52.91\left(\mathrm{~N}-\alpha-\mathrm{CH}_{2}\right), 56.02 \quad(\mathrm{~N}-$ $\left.\alpha-\mathrm{CH}_{2}\right), 57.36\left(\mathrm{~N}-\alpha-\mathrm{CH}_{2}\right), 58.41\left(\mathrm{~N}-\alpha-\mathrm{CH}_{2}\right), 59.16\left(\mathrm{~N}-\alpha-\mathrm{CH}_{2}\right)$, $127.09\left(\mathrm{C}_{\text {aromatic }}\right), 130.23$ ( $\left.\mathrm{C}_{\text {aromatic }}\right), 133.98$ ( $\left.\mathrm{C}_{\text {aromatic }}\right), 135.62$ $\left(\mathrm{C}_{\text {aromatic }}\right)$. Anal. calcd for $\mathrm{C}_{34} \mathrm{H}_{62} \mathrm{~N}_{8} \cdot 8 \mathrm{HCl} \cdot 5.05 \mathrm{H}_{2} \mathrm{O}: \mathrm{C} 42.29, \mathrm{H}$ 8.36, N 11.60; found: C 42.66, H 8.64, N 11.21. MS (ES): $m / z=$ $584[\mathrm{M}+\mathrm{H}]^{+}$.

\section{Synthesis of $[\mathrm{Ni1}]\left(\mathrm{NO}_{3}\right)_{4}$}

1 (200 mg, $0.36 \mathrm{mmol})$ was dissolved in methanol $(20 \mathrm{~mL})$ and a methanolic $(5 \mathrm{~mL})$ solution of nickel(II) nitrate hexahydrate (230 $\mathrm{mg}, 0.79 \mathrm{mmol}$ ) was added dropwise. The mixture was heated to $60{ }^{\circ} \mathrm{C}$ for 30 minutes under nitrogen, then stirred at RT overnight. The resulting solution was concentrated to $\sim 5 \mathrm{~mL}$ in vacuo then purified via size exclusion chromatography (sephadex LH20) to yield an orange solid. Yield $=87 \%$. HRMS: $\left[\mathrm{M}-4 \mathrm{NO}_{3}-2 \mathrm{H}\right]^{2+}$ calcd for $\mathrm{C}_{32} \mathrm{H}_{56} \mathrm{~N}_{8} \mathrm{Ni}_{2} \mathrm{~m} / z=334.1663$, found $m / z=334.1662$. Anal. calcd for $\mathrm{C}_{32} \mathrm{H}_{56} \mathrm{Ni}_{2} \mathrm{~N}_{12} \mathrm{O}_{12}$. $2 \mathrm{CH}_{3} \mathrm{OH}$ : C, 41.49; H, 6.76; N, 17.08; found $\mathrm{C}, 41.11 ; \mathrm{H}, 6.70$; $\mathrm{N}, 16.78$. UV-vis. $(\mathrm{MeOH}): \lambda_{\max } 483 \mathrm{~nm}, \varepsilon=396 \mathrm{M}^{-1} \mathrm{~cm}^{-1}$.

\section{Synthesis of $[\mathrm{Ni2}]\left(\mathrm{NO}_{3}\right)_{2}$}

The same method was used as for the synthesis of $[\mathrm{Ni1}]\left(\mathrm{NO}_{3}\right)_{4}$ with the following amounts: 1-[4-aminomethylbenzyl]-1,4,8,11tetraazabicyclo[10.2.2] hexadecane (2) (110 mg, $0.32 \mathrm{mmol})$ was dissolved in methanol $(10 \mathrm{~mL})$ and nickel(II) nitrate hexahydrate $(102 \mathrm{mg}, 0.35 \mathrm{mmol})$. Yield $=63 \%$. HRMS: $\mathrm{M}^{2+}$ calcd for $\mathrm{C}_{20} \mathrm{H}_{35} \mathrm{~N}_{5} \mathrm{Ni} \mathrm{m} / \mathrm{z}=201.6118$, found $\mathrm{m} / \mathrm{z}=201.6117$. Anal. calcd for $\mathrm{C}_{20} \mathrm{H}_{34} \mathrm{~N}_{7} \mathrm{NiO}_{6}$ : C, 42.37; H, 7.11; N, 16.47; found $\mathrm{C}, 42.51 ; \mathrm{H}, 6.88 ; \mathrm{N}, 16.64$. UV-vis. $\left(\mathrm{H}_{2} \mathrm{O}\right)$ : $\lambda_{\max } 476 \mathrm{~nm}$, $\varepsilon=174 \mathrm{M}^{-1} \mathrm{~cm}^{-1}$.

\section{Synthesis of $[\mathrm{Ni3}]\left(\mathrm{CH}_{3} \mathrm{CO}_{2}\right)_{2}\left(\mathrm{PF}_{6}\right)_{2}$}

In an inert atmosphere glovebox, $3(0.437 \mathrm{~g}, 0.75 \mathrm{mmol})$ was dissolved in DMF $(20 \mathrm{~mL})$ and anhydrous $\mathrm{Ni}\left(\mathrm{CH}_{3} \mathrm{CO}_{2}\right)_{2}$ (0.265 $\mathrm{g}, 1.5 \mathrm{mmol})$ was added with stirring. The solution was heated to $c a .60{ }^{\circ} \mathrm{C}$ overnight. The reaction mixture was removed from the glovebox, filtered to remove trace solids, evaporated to dryness and dried in vacuo. The brown solid was dissolved in $4 \mathrm{ml}$ of dry methanol and $\mathrm{NH}_{4} \mathrm{PF}_{6}(1.22 \mathrm{~g}, 7.5 \mathrm{mmol})$, dissolved in an additional $4 \mathrm{~mL}$ of dry methanol, was added dropwise to the stirring complex solution. A fine, brown precipitate formed. Completion of precipitation was achieved by storing the mixture overnight at $-5{ }^{\circ} \mathrm{C}$. The brown solid product was collected by filtration on a fine frit, washed with cold methanol and then ether and dried in vacuo. Yield $=0.413 \mathrm{~g}(56 \%)$. The elemental analysis is satisfactory as a mixed acetate/hexafluorophosphate salt, $\left[\mathrm{Ni}_{2} 3\left(\mathrm{CH}_{3} \mathrm{CO}_{2}\right)_{2.1}\right]\left(\mathrm{PF}_{6}\right)_{1.9}$. Anal. calcd for $\mathrm{C}_{38.2} \mathrm{H}_{68.3} \mathrm{~F}_{5.4} \mathrm{Ni}_{2}-$ $\mathrm{N}_{8} \mathrm{O}_{4.2} \mathrm{P}_{1.9}$ : C, 41.72; H, 6.26; N, 10.19; found $\mathrm{C}, 42.02 ; \mathrm{H}$, 6.37; N, 9.87. MS (ES): $m / z=961.2\left[\mathrm{M}-\mathrm{PF}_{6}\right]^{+}$. UV-vis. $\left(\mathrm{H}_{2} \mathrm{O}\right): \lambda_{\max } 376 \mathrm{sh}, 561 \mathrm{sh}, 897 \mathrm{~nm}$.

\section{Synthesis of $[\mathrm{Ni8}]\left(\mathrm{ClO}_{4}\right)_{2}$}

8 (1.19 g, $2.4 \mathrm{mmol})$ was dissolved in acetonitrile $(20 \mathrm{~mL})$ and $\mathrm{Ni}\left(\mathrm{ClO}_{4}\right)_{2} \cdot 6 \mathrm{H}_{2} \mathrm{O}(0.91 \mathrm{~g}, 2.5 \mathrm{mmol})$ in acetonitrile $(20 \mathrm{~mL})$ was added dropwise whilst stirring. The crude product was purified using size exclusion chromatography (sephadex LH20). The solvent was then removed from the orange solution, producing an orange crystalline solid, and dried in vacuo. Yield $=71 \%$. ${ }^{1} \mathrm{H}$ NMR (400 MHz, $\mathrm{CDCl}_{3}, \delta$ ): 1.31-1.38 (m, 2H, N- $\beta-\mathrm{CH}_{2}$ ), $1.64-1.75\left(\mathrm{~m}, 2 \mathrm{H}, \mathrm{N}-\beta-\mathrm{CH}_{2}\right) 2.08-2.15\left(\mathrm{~m}, 8 \mathrm{H}, \mathrm{N}-\alpha-\mathrm{CH}_{2}\right)$, 2.21-2.31 (m, 2H, N- $\left.\alpha-\mathrm{CH}_{2}\right), 2.38-2.55$ (m, 2H, N- $\alpha-\mathrm{CH}_{2}$ ), 
2.62-2.78 (m, 2H, N- $\alpha-\mathrm{CH}_{2}$ ), 2.83-2.2.96 (m, 2H, N- $\alpha-\mathrm{CH}_{2}$ ), $3.12-3.21\left(\mathrm{~m}, 2 \mathrm{H}, \mathrm{N}-\alpha-\mathrm{CH}_{2}\right), 3.33-3.47$ (m, 2H, N- $\left.\alpha-\mathrm{CH}_{2}\right)$, $3.56\left(\mathrm{~s}, 3 \mathrm{H}, \mathrm{N}-\mathrm{CH}_{3}\right),{ }^{13} \mathrm{C}\left\{{ }^{1} \mathrm{H}\right\} \mathrm{NMR}\left(100 \mathrm{MHz}, \mathrm{CDCl}_{3}, \delta\right)$ : $21.31\left(\mathrm{~N}-\beta-\mathrm{CH}_{2}\right), 24.2\left(\mathrm{~N}-\beta-\mathrm{CH}_{2}\right), 39.11\left(\mathrm{~N}-\mathrm{CH}_{3}\right), 45.21(\mathrm{~N}-$ $\left.\alpha-\mathrm{CH}_{2}\right), 47.44\left(\mathrm{~N}-\alpha-\mathrm{CH}_{2}\right), 51.88\left(\mathrm{~N}-\alpha-\mathrm{CH}_{2}\right), 52.31\left(\mathrm{~N}-\alpha-\mathrm{CH}_{2}\right)$, $55.13\left(\mathrm{~N}-\alpha-\mathrm{CH}_{2}\right), 58.13\left(\mathrm{~N}-\alpha-\mathrm{CH}_{2}\right), 59.11\left(\mathrm{~N}-\alpha-\mathrm{CH}_{2}\right), 59.97$ $\left(\mathrm{N}-\alpha-\mathrm{CH}_{2}\right)$. MS (ES): $m / z=297 \mathrm{M}^{+}$.

\section{Synthesis of $\left[\mathrm{Ni9OAc}\left(\mathrm{OH}_{2}\right)\right] \mathrm{PF}_{6}$}

In an inert atmosphere glovebox, $0.177 \mathrm{~g}(0.001 \mathrm{~mol})$ of nickel (II) acetate and $0.254 \mathrm{~g}(0.001 \mathrm{~mol})$ of 9 were stirred in $25 \mathrm{~mL}$ of anhydrous acetonitrile and heated to $50-60{ }^{\circ} \mathrm{C}$ overnight. The reaction mixture was then removed from the glovebox, filtered through filter paper and the acetonitrile evaporated. The remaining nickel complex was dried in vacuo overnight to remove any solvent, leaving a hygroscopic purple powder. This powder was dissolved in $3 \mathrm{ml}$ of anhydrous methanol. Five equivalents ( $0.005 \mathrm{~mol}, 0.815 \mathrm{~g})$ of $\mathrm{NH}_{4} \mathrm{PF}_{6}$ dissolved in $3 \mathrm{~mL}$ of anhydrous methanol were added dropwise to the stirring metal complex, causing precipitation of a pale purple powder. The reaction mixture was stored overnight in a freezer to complete the precipitation. A pale purple powder was collected on a fine glass frit, washed with cold methanol and ether and dried in vacuo. Yield: $0.343 \mathrm{~g}(75 \%)$. X-ray quality crystals, pale purple plates, were grown from an ether diffusion into a nitromethane solution. Elemental analysis (\%) calcd $\left[\mathrm{NiC}_{14} \mathrm{H}_{30} \mathrm{~N}_{4}\left(\mathrm{C}_{2} \mathrm{H}_{3} \mathrm{O}_{2}\right)\right]\left(\mathrm{PF}_{6}\right) \cdot 1.5$ $\mathrm{H}_{2} \mathrm{O}$ : C 35.32, H 6.67, $\mathrm{N}$ 10.30; Found $\mathrm{C} 35.46, \mathrm{H} 6.68$, $\mathrm{N} 10.10$. MS (ES) $m / z=371[\mathrm{Ni9}(\mathrm{OAc})]^{+}, 331\left[\mathrm{Ni9}\left(\mathrm{H}_{2} \mathrm{O}\right)\right]^{+}$.

\section{Synthesis of $\left[\mathrm{Ni10OAc}\left(\mathrm{OH}_{2}\right)\right] \mathrm{PF}_{6} \cdot \mathrm{MeOH}$}

In an inert atmosphere glovebox, $0.177 \mathrm{~g}(0.001 \mathrm{~mol})$ of nickel (II) acetate and $0.406 \mathrm{~g}(0.001 \mathrm{~mol})$ of $\mathbf{1 0}$ were stirred in $25 \mathrm{~mL}$ of anhydrous DMF at room temperature for 18 hours. The reaction mixture was then removed from the glovebox, filtered to remove any trace solids and evaporated to dryness. The pale blue solid residue was dissolved in $10 \mathrm{~mL}$ of dry methanol to which a $5 \mathrm{~mL}$ dry methanol solution of 5 equivalents $(0.815 \mathrm{~g}$, $5.00 \mathrm{mmol}$ ) of $\mathrm{NH}_{4} \mathrm{PF}_{6}$ was added dropwise. A pale purple powder precipitated, was collected on a fine glass frit, washed with cold methanol and ether and dried in vacuo. Yield: $0.584 \mathrm{~g}$ (91\%). X-ray quality crystals, pale blue needles, were obtained from a cooled methanol solution. The elemental analysis is satisfactory as a mixed acetate/hexafluorophosphate salt. Elemental analysis (\%) calcd $\left[\mathrm{NiC}_{26} \mathrm{H}_{38} \mathrm{~N}_{4}\left(\mathrm{C}_{2} \mathrm{H}_{3} \mathrm{O}_{2}\right)\right]\left(\mathrm{C}_{2} \mathrm{H}_{3} \mathrm{O}_{2}\right)_{0.25}(\mathrm{PF} 6)_{0.75}$ : C 52.84, H 6.50, N 8.65; Found C 52.54, H 6.67, N 9.01. MS (ES): $m / z=523.3[\mathrm{Ni10}(\mathrm{OAc})]^{+}$.

\section{Chemokine-induced calcium signalling assay}

$\mathrm{Ca}^{2+}$ mobilization assays were performed by the use of a fluorometric imaging plate reader (FLIPR) (Molecular Devices, Sunnyvale, USA) as described previously. ${ }^{49}$ Briefly, U87.CXCR4 cells were loaded with the fluorescent calcium indicator Fluo-3 acetoxymethyl (Molecular Probes, Leiden, The Netherlands) in the appropriate culture medium for 45 minutes at $37{ }^{\circ} \mathrm{C}$, after which the cells were washed three times in a Hanks balanced salt solution buffer containing $20 \mathrm{mM}$ HEPES and $0.2 \%$ bovine serum albumin ( $\mathrm{pH}$ 7.4). The cells were then incubated in the dark at $37{ }^{\circ} \mathrm{C}$ for 15 minutes with the compounds. Changes in the intracellular calcium concentration upon the addition of CXCL12 (SDF-1), the specific ligand for CXCR4, was simultaneously measured in all 96 wells in a black-wall microtiter plate and in real time with the FLIPR. The data was expressed as fluorescence units versus time and was analyzed using the Softmax PRO 4.0 program (Molecular Devices) and $\mathrm{IC}_{50}$ values were calculated using the GraphPad Prism 4.0 software (San Diego, CA).

\section{Anti-viral assays}

Anti-HIV activity and cytotoxicity measurements in MT-4 and other cells were based on the viability of the cells that had been infected or not infected with HIV-1, HIV-2 or SIV and exposed to various concentrations of the test compound. ${ }^{50}$ After the cells were allowed to proliferate for 5 days, the number of viable cells was quantified by a tetrazolium-based colorimetric method, as described by Pauwels et al. ${ }^{51,52}$ PBMCs were purified and infected with HIV and SIV, as described in detail by Schols et al. ${ }^{53}$

\section{Acknowledgements}

We would like to acknowledge the University of Hull for an 80th Anniversary studentship awarded to RS and the EPSRC for funds to purchase the diffractometer on which the X-ray data were collected. SJA thanks the Yorkshire Forward for the award of a Yorkshire Enterprise Fellowship in translational molecular imaging technologies. We would also like to acknowledge the use of the EPSRC's National Mass Spectrometry Service Centre at Swansea and the Chemical Database Service at Daresbury. This project was supported by the National Center for Research Resources and the National Institute of General Medical Sciences of the National Institutes of Health through Grant Number 8P20GM103447. This work was also supported by the FWO (G.0528.12 N) and the KU Leuven (PF/10/018 and GOA/10/014).

\section{References}

1 P. M. Murphy, I. F. Charo, R. Hills, R. Horuk, K. Matsushima and J. J. Oppenheim, Chemokine receptors. Last modified on 29/02/2012. Accessed on 31/03/2012. IUPHAR database (IUPHAR-DB), http://www. iuphar-db.org/DATABASE/FamilyMenuForward?familyId=14.

2 A. Khan, J. Greenman and S. J. Archibald, Curr. Med. Chem., 2007, 14, $2257-2277$.

3 E. De Clercq, Curr. Opin. Pharmacol., 2010, 10, 507-515.

4 J. A. Esté, C. Cabrera, E. De Clercq, S. Struyf, J. Van Damme, G. Bridger, R. T. Skerlj, M. J. Abrams, G. Henson, A. Gutierrez, B. Clotet and D. Schols, Mol. Pharmacol., 1999, 55, 67-73.

5 S. Hatse, K. Princen, L. O. Gerlach, G. Bridger, G. Henson, E. De Clercq, T. W. Schwartz and D. Schols, Mol. Pharmacol., 2001, 60, 164-173.

6 E. De Clercq, Nat. Rev. Drug Discovery, 2003, 2, 581-587.

7 G. A. Donzella, D. Schols, S. W. Lin, J. A. Este, K. A. Nagashima, P. J. Maddon, G. P. Allaway, T. P. Sakmar, G. Henson, E. De Clercq and J. P. Moore, Nat. Med., 1998, 4, 72-77.

8 E. De Clercq, Nat. Rev. Drug Discovery, 2003, 2, 581-587. 
9 W. C. Liles, H. E. Broxmeyer, E. Rodger, B. Wood, K. Hübel, S. Cooper, G. Hangoc, G. J. Bridger, G. W. Henson, G. Calandra and D. C. Dale, Blood, 2003, 102, 2728-2730.

10 D. Schols, Antiviral Res., 2006, 71, 216-226.

11 E. T. Roussos, J. S. Condeelis and A. Patsialou, Nat. Rev. Cancer, 2011, $11,573-587$.

12 A. Khan, J. D. Silversides, L. Madden, J. Greenman and S. J. Archibald, Chem. Commun., 2007, 416-418.

13 G. McRobbie, G. C. Valks, C. J. Empson, A. Khan, J. D. Silversides, C. Pannecouque, E. De Clercq, S. G. Fiddy, A. J. Bridgeman, N. A. Young and S. J. Archibald, Dalton Trans., 2007, 5008-5018.

14 A. Khan, G. Nicholson, J. Greenman, L. Madden, G. McRobbie, C. Pannecouque, E. De Clercq, R. Ullom, D. L. Maples, R. L. Maples, J. D. Silversides, T. J. Hubin and S. J. Archibald, J. Am. Chem. Soc., 2009, 131, 3416-3417.

15 N. Cade, G. Fruhwirth, S. J. Archibald, T. Ng and D. Richards, in Biophotonics: Photonic Solutions for Better Health Care Ii, ed. J. Popp, V. V. Tuchin and D. L. Matthews, 2010, vol. 7715

16 N. I. Cade, G. Fruhwirth, S. J. Archibald, T. Ng and D. Richards, Biophys. J., 2010, 98, 2752-2757.

17 L. O. Gerlach, J. S. Jakobsen, K. P. Jensen, M. R. Rosenkilde, R. T. Skerlj, U. Ryde, G. J. Bridger and T. W. Schwartz, Biochemistry, 2003, 42, 710-717.

18 J. A. Este, M. A. Martinez, A. Gutierrez, M. Armand-Ugon, J. Blanco, M. Parera, J. Gomez and B. Clotet, AIDS, 2002, 16, 2385-2390.

19 E. A. Lewis, C. C. Allan, R. W. Boyle and S. J. Archibald, Tetrahedron Lett., 2004, 45, 3059-3062.

20 E. A. Lewis, R. W. Boyle and S. J. Archibald, Chem. Commun., 2004, 2212-2213.

21 J. D. Silversides, C. C. Allan and S. J. Archibald, Dalton Trans., 2007, 971-978.

22 R. E. Mewis and S. J. Archibald, Coord. Chem. Rev, 2010, 254, 1686-1712.

23 J. D. Silversides, R. Smith and S. J. Archibald, Dalton Trans., 2011, 40, 6289-6297.

24 E. H. Wong, G. R. Weisman, D. C. Hill, D. P. Reed, M. E. Rogers, J. S. Condon, M. A. Fagan, J. C. Calabrese, K. C. Lam, I. A. Guzei and A. L. Rheingold, J. Am. Chem. Soc., 2000, 122, 10561-10572.

25 C. A. Boswell, X. K. Sun, W. J. Niu, G. R. Weisman, E. H. Wong, A. L. Rheingold and C. J. Anderson, J. Med. Chem., 2004, 47, $1465-1474$

26 N. Bernier, M. Allali, R. Tripier, F. Conan, V. Patinec, S. Develay, M. Le Baccon and H. Handel, New J. Chem., 2006, 30, 435-441.

27 N. Bernier, J. Costa, R. Delgado, V. Felix, G. Royal and R. Tripier, Dalton Trans., 2011, 40, 4514-4526.

28 B. Bosnich, C. K. Poon and M. L. Tobe, Inorg. Chem., 1965, 4, 1102.

29 G. C. Valks, G. McRobbie, E. A. Lewis, T. J. Hubin, T. M. Hunter, P. J. Sadler, C. Pannecouque, E. De Clercq and S. J. Archibald, J. Med. Chem., 2006, 49, 6162-6165.
30 T. M. Hunter, I. W. McNae, D. P. Simpson, A. M. Smith, S. Moggach, F. White, M. D. Walkinshaw, S. Parsons and P. J. Sadler, Chem.-Eur. J., $2007,13,40-50$

31 M. Le Baccon, F. Chuburu, L. Toupet, H. Handel, M. Soibinet, I. Dechamps-Olivier, J. P. Barbiere and M. Aplincourt, New J. Chem., 2001, 25, 1168-1174.

32 R. D. Hancock, G. Pattrick, P. W. Wade and G. D. Hosken, Pure Appl. Chem., 1993, 65, 473-476.

33 F. H. Allen, Acta Crystallogr., Sect. B: Struct. Sci., 2002, 58, 380-388.

34 A. Ramasubbu and K. P. Wainwright, J. Chem. Soc., Chem. Commun., 1982, 277-278

35 R. D. Hancock, S. M. Dobson, A. Evers, P. W. Wade, M. P. Ngwenya, J. C. A. Boeyens and K. P. Wainwright, J. Am. Chem. Soc., 1988, 110, 2788-2794

36 T. Hubin, N. Alcock, H. Clase and D. Busch, Supramol. Chem., 2001, 13, 261.

37 X. Y. Liang, J. A. Parkinson, M. Weishaupl, R. O. Gould, S. J. Paisey, H. S. Park, T. M. Hunter, C. A. Blindauer, S. Parsons and P. J. Sadler, J. Am. Chem. Soc., 2002, 124, 9105-9112.

38 J. Nishigaki, T. Matsumoto and K. Tatsumi, Eur. J. Inorg. Chem., 2010, 5011.

39 A. Szumna, M. Achmatowicz, T. Zielinski and J. Jurczak, Polyhedron, 2005, 24, 2981.

40 L. Jiang, X.-L. Feng and T.-Bu Lu, Cryst. Growth Des., 2005, 5, 1469.

41 E. K. Barefield, F. Wagner, A. W. Herlinger and A. R. Dahl, Inorg. Synth., 1976, 16, 220.

42 R. A. Kolinski, Pol. J. Chem., 1995, 69, 1039-1045.

43 D. Bradley, G. Williams and M. Lawton, J. Org. Chem., 2010, 75, $8351-8354$.

44 J. Cosier and A. M. Glazer, J. Appl. Crystallogr., 1986, 19, 105-107.

45 G. M. Sheldrick, SHELXS-97 Program for Crystal Structure Solution, Institüt für Anorganische Chemie der Universität, Tammanstrasse 4, D-3400 Gottingen, Germany, 1997.

46 G. M. Sheldrick, SHELXL-97 Program for Crystal Structure Refinement, Institüt für Anorganische Chemie der Universität, Tammanstrasse 4, D-3400 Gottingen, Germany, 1997.

47 L. J. Farrugia, J. Appl. Crystallogr., 1999, 32, 837-838.

48 S. K. Wolff, D. J. Grimwood, J. J. McKinnon, D. Jayatilaka and M. A. Spackman, CrystalExplorer v2.1, University of Western Australia, Perth, Australia, 2007.

49 K. Princen, S. Hatse, K. Vermeire, E. De Clercq and D. Schols, Cytometry, 2003, 51A, 35-45.

50 S. Harada, Y. Koyanagi and N. Yamamoto, Science, 1985, 229, 563-566.

51 R. Pauwels, J. Balzarini, M. Baba, R. Snoeck, D. Schols, P. Herdewijn, J. Desmyter and E. De Clercq, J. Virol. Methods, 1988, 20, 309-321.

52 C. Pannecouque, D. Daelemans and E. De Clercq, Nat. Protoc., 2008, 3, 427-434.

53 D. Schols, S. Struyf, J. VanDamme, J. A. Este, G. Henson and E. De Clercq, J. Exp. Med., 1997, 186, 1383-1388. 